\title{
No chance for romance: \\ Corporate culture, gendered work, and increased singlehood in Japan
}

\author{
AKIKO YOSHIDA
}

\begin{abstract}
This paper is part of a larger study that investigates the cause of increased singlehood among women in Japan. On the basis of findings from qualitative research this paper argues that Japanese corporate practices and culture have severely limited women's opportunities for romantic encounters. In-depth, open-ended interviews were conducted in the Tokyo area with forty never-married and married women aged 25 to 46. The data were analyzed inductively. The findings reveal that long work hours for men, and in some cases for women, impeded opportunities for women to form romantic relationships in several ways: (i) men were seldom available; (ii) many married women expressed discontent with marriage due to the absence of husbands; many single women held ambivalent views toward marriage after having heard negative stories from married friends; (iii) some single women found it unappealing that corporate men could talk about nothing but work; and (iv) single women with careers regularly worked overtime and their devotion to work was regarded as "unfeminine". Additionally, workplaces are often segregated by gender, further limiting opportunities for single women to meet potential partners. This paper sheds critical light on the culture and practices of Japanese corporations, arguing that such culture and practices create serious consequences for individuals' lives.
\end{abstract}

Keywords: Japan; singlehood; gender; gender segregation; corporate culture; employment segregation; romantic relationships; workplace requirements; qualitative research; lifestyle. 


\section{ロマンスの機会なし：日本における企業文化・ジェンダード・ワー クと独身者の増加}

吉田 亜紀子 本稿は日本における未婚女性の増加の原因を探求する研究の一部であ る。質的調査の結果、本稿は、日本企業の雇用形態と文化が女性の出 会いや恋愛の機会を著しく狭めているとの結論に達した。

本研究では、首都圏在住の25歳から46歳までの未婚および既婚女性40 人と時間制限のない掘り下げたインタービューを行い、データを帰納 法を用いて分析した。その結果、男 性や一部の女性の長時間勤務が、 女性にとり恋愛関係を築く上で様々な形で妨げになっていることが明 らかになった。中でも（1）周囲に男性があまりいない、（2）多く の既婚女性は夫がなかなか帰宅しないため結婚生活に不満を感じてい る。結婚した友人から結婚についてネガティブな話を聞いた独身女性 は結婚について曖昧な態度を示す。（3）未婚女性の中には、仕事以外 の話をしない男性に魅力を感じないという人がいる。（4） キャリア のある未婚女性はたびたび残業しており、その様に仕事に没頭するこ とは「可愛くない」と思われていることが判明した。さらに、職場が しばしば男女別に分かれているので、女性にとり結婚相手として相応 しい男性に出会う機会が限られている。

本稿は、日本企業のこのような文化と職場環境が恋愛や結婚といった 個人の人生に深刻な結果をもたらすことを指摘するものである。

\section{Introduction}

The proportion of never-married women has increased significantly in Japan, most notably since the 1980s, and unprecedented numbers of Japanese women remain single in all age groups today (MIAC 2008). Unlike their Western counterparts, most single women in Japan are not cohabiters or unwed mothers, but live with their parents or alone (Rindfuss et al. 2004). However, a great majority of Japanese women expressed their intention to marry throughout the time marriage rates declined (NIPSSR 2008), and therefore increased singlehood does not seem to reflect a declined interest in marriage. Why, then, do so many Japanese women remain single today?

This paper is part of a larger study that investigates the cause of increased singlehood among women in Japan. ${ }^{1}$ In the summer of 2009, in-depth interviews were conducted with forty never-married and married women in the Tokyo area. The findings suggest that women's opportunities for romantic encounters were limited by corporate practices and culture, including gender segregation at work, long work hours, and meanings attached to women's careers. This study argues that sin- 
glehood in Japan is caused partly by this limitation in chances for romance, a consequence of the tension between existing power structures and individual desires.

\section{Marriage decline in Japan and its explanations}

Japan's marriage rates began to decline significantly in the 1980 s and continued to decline afterwards. In 1970 , only $18.1 \%$ of women between 25 and 29 had never been married, but the corresponding figure increased to $59.9 \%$ in 2005. Part of the reason for increased singlehood is delayed marriage, as the average age for first marriage for women rose from 24.2 in 1970 to 27.8 in 2005 . However, the proportions of never-married females have gone up for older age groups as well. Between 1970 and 2005, for the age groups 30-34, 35-39, 40-44, and $45-49$, the rates increased from $7.2 \%$ to $32.6 \%, 5.8 \%$ to $18.6 \%, 5.3 \%$ to $12.2 \%$, and $4.0 \%$ to $7.9 \%$, respectively (MIAC 2008). Thus, the increased singlehood among women cannot be explained solely by postponement of marriage. Further, the phenomenon does not seem to reflect a declined interest in marriage, as a great majority of women expressed their intention to marry (NIPSSR 2008), and alternative intimate relationships such as cohabitation and unwed motherhood remain rare (Raymo et al. 2009; Rindfuss et al. 2004). Additionally, the sex ratios have been higher (i.e., more males than females) (Retherford et al. 2001; Tokuhiro 2010) and therefore there has been no shortage in the male population from which (heterosexual) women choose partners (Guttentag and Secord 1983).

There are several sociological theories that attempt to explain declining marriage rates in industrial nations. Neo-classical economic theorists (e.g., Becker 1993 [1981]) point to women's increased economic independence as the cause, whereas other economic theorists (e.g., Oppenheimer 2000; Oppenheimer et al. 1997) argue that the cause lies in deteriorating economic prospects among young males. Cultural sociology (see, e.g., Beck and Beck-Gernsheim 2005; Cherlin 2004; Giddens 1991; Van de Kaa 1987), on the other hand, provides theories that contend that an ideational shift to individualism and secularization has led to the decline of marriage as an institution.

Empirical findings in Japan, however, do not support such economic theories. Within the age cohort experiencing rapid marriage decline, marriage rates dropped for all levels of education and occupation of women and men (Atoh 1994; Hiroshima 1999; Iwama 1999; Raymo 2003; Tsuya and Mason 1995). ${ }^{2}$ Although the Japanese may be becoming more individualistic, no clear explanation has been given for how and why individualistic values necessarily translate into singlehood 
(Tsuya and Mason 1995). Therefore, possible structural barriers that may impede individuals' decision making need to be examined.

The importance of a better understanding of the phenomenon of increased singlehood in Japan cannot be overstated. First, it has a theoretical implication because Japan may provide a case that challenges existing theories, formed mostly from Western experiences. The Japanese case might help refine and strengthen theories of non-marriage. Second, this phenomenon is directly linked to the issue of Japan's below-replacement fertility level (MHLW 2003). Tackling this problem requires answers to the question of why more people remain single. And, third, it is likely that many single women suffer economically, and yet are often neglected by state policies. Japanese women do not fare well economically compared to men in Japan and to women in other industrial nations (e.g., Kerbo 2009; Rebick 2006; Tachibanaki 2006). Single women in particular are more vulnerable because, for instance, corporate and state benefits typically target family households (Hirayama and Izuhara 2008), and many never-married women depend financially on their parents (Tsuya 2000). Despite the fact that economic conditions are largely shaped by gender and marital status in Japan, never-married women are often portrayed as "selfish" or "free" in public discourse (Nakano and Wagatsuma 2004), a perception that may take its toll on their well-being.

\section{Method}

In order to find out why many Japanese women remain single, original data were collected through in-depth, semi-structured, face-to-face interviews and then analyzed inductively. The interviews were conducted with forty Japanese never-married and married women aged 25 to 46 in the Greater Tokyo Area between May and July of 2009. The sample was drawn using a combination of purposive, convenience, and snowball sampling methods. I contacted several acquaintances I had in Japan and asked whether they could introduce me to potential research participants. These acquaintances were diverse in age, level of education, and occupational status. Upon each interview's completion, I asked interviewees to provide me with referrals to their friends, coworkers, etc. Because I wanted to have approximately equal representation in three age groups (twenties, thirties, and forties) and a larger sample of nevermarried than married women, I sometimes requested referrals of specific age and marital status.

I focused on residents in the Tokyo area for two main reasons. First, Tokyo has the highest single population in Japan and, therefore, singlehood is most conspicuous in this area. Second, for a qualitative study, 
Table 1. Interview participants.

\begin{tabular}{llllll}
\hline Never-married & & & & \\
Name & Age & Education* & Occupation** & Income*** & Romantic partner \\
\hline Izumi & 46 & Univ & marketing researcher & $>7 \mathrm{M}$ & No \\
Kazuko & 45 & M.A. & artist/instructor & "small" & No \\
Sumire & 45 & M.S. & pharmacist & $5 \mathrm{M}$ & No \\
Kozue & 45 & 2-yr col & clerical worker & $6-7 \mathrm{M}$ & Yes $(2$ men) \\
Rumi & 45 & 2-yr col & advertising & $>7 \mathrm{M}$ & No \\
Saori & 45 & Voc & clerical worker & "small" & No \\
Seiko & 43 & M.A. & accountant & $>7 \mathrm{M}$ & Yes \\
Tsuneko & 43 & Univ & marketing consultant & $5-6 \mathrm{M}$ & No \\
Natsumi & 43 & Univ & illustrator (F) & $4-5 \mathrm{M}$ & No \\
Teruko & 41 & Univ & graphic designer (F) & not disclosed & Yes (married \\
& & & & & man) \\
Tomomi & 39 & Voc & social worker & $3-3.5 \mathrm{M}$ & No \\
Midori & 36 & Univ & advertising & $3.5-4 \mathrm{M}$ & Yes (cohabiting) \\
Hitomi & 36 & Univ & marketing consultant & $5 \mathrm{M}$ & No \\
Yoko & 36 & Voc & section manager & $5.5 \mathrm{M}$ & Yes \\
Kei & 35 & Voc & clerical worker & $2.5-3 \mathrm{M}$ & No \\
Shizuka & 34 & Voc & clerical worker & $2.5-3 \mathrm{M}$ & No \\
Honoka & 32 & Voc & marketing consultant & $5.5 \mathrm{M}$ & No \\
Mutsumi & 32 & Voc & clerical worker (T) & $3-3.5 \mathrm{M}$ & Yes \\
Yuri & 32 & High s & clerical worker & $3.5-4 \mathrm{M}$ & Yes (engaged) \\
Megumi & 31 & Univ & clerical worker & $4-4.5 \mathrm{M}$ & No \\
Yayoi & 31 & Univ & clerical worker (T) & $2-2.5 \mathrm{M}$ & No \\
Momoe & 30 & Univ & clerical worker & $4 \mathrm{M}$ & No \\
Ran & 29 & M.D. & medical researcher & $4 \mathrm{M}$ & Yes (engaged) \\
Shoko & 29 & $2-$-yr col & homecare worker & $2-2.5 \mathrm{M}$ & Yes \\
Junko & 27 & M.A. & secretary & $3 \mathrm{M}$ & Yes \\
Ryoko & 26 & Univ & unemployed & - & Yes (cohabiting) \\
Maya & 26 & Univ & unemployed & - & Yes (lesbian) \\
Yuki & 26 & Univ & receptionist (P) & $<1 \mathrm{M}$ & Yes (cohabiting) \\
\hline & & & & & \\
\hline
\end{tabular}

\begin{tabular}{|c|c|c|c|c|}
\hline $\begin{array}{l}\text { Married } \\
\text { Name }\end{array}$ & Age & Education* & Occupation** & Income ${ }^{* * *}$ \\
\hline Eri & 46 & Univ & secretary $(\mathrm{P})$ & $<2 \mathrm{M}$ \\
\hline Tamami & 45 & Univ & social worker $(\mathrm{P})$ & $2-2.5 \mathrm{M}$ \\
\hline Sonoko & 45 & 2-yr col & store clerk $(\mathrm{P})$ & $<2 \mathrm{M}$ \\
\hline Chie & 45 & High s & clerical worker $(\mathrm{P})$ & $<2 \mathrm{M}$ \\
\hline Nozomi & 40 & Voc & housewife & - \\
\hline Harumi & 39 & High s & housewife & - \\
\hline Fujiko & 38 & Univ & housewife & - \\
\hline Mari & 38 & 2-yr col & housewife & - \\
\hline Akane & 34 & Univ & housewife & - \\
\hline Rika & 29 & 2-yr col & dental assistant $(\mathrm{P})$ & $<1 \mathrm{M}$ \\
\hline Kyoko & 29 & Voc & cook & $2-3 \mathrm{M}$ \\
\hline Kimi & 25 & Univ & bank teller & $3.5-4 \mathrm{M}$ \\
\hline
\end{tabular}

* High s = high school; Voc = vocational school $($ senmon gak $k \bar{o}) ; 2-\mathrm{yr}$ col = 2year college; Univ = 4-year university; M.A. = Master of Arts; M.S. = Master of Science; M.D. = Medical Degree.

** $\quad \mathrm{F}=$ freelance; $\mathrm{T}=$ temporary staff; $\mathrm{P}=$ part-time.

$* * *$ Net income in million yen. 
the sample size would have to be small. I decided to focus on Tokyo residents in order to control for possible effects of regional and urbanrural differences in women's experiences.

Brief profiles of interview participants are provided in Table 1 (all names are pseudonyms). Interviewees were diverse in terms of education, occupation, and income. Twenty-eight interviewees were nevermarried and twelve were married at the time of the interviews.

The interviews were conducted in Japanese, which is my first language, and recorded and transcribed by me. I followed the prepared interview guide and asked questions on various subjects including job history, work environment, past and current relationships, ideal life course, merits of marriage and singlehood, intention to marry, ideal age to marry, ideal marital partners, views concerning gender roles and parents' and peer marriages, ways leisure time was spent, social networks, future concerns, and demographic information. ${ }^{3}$ Interviewees were encouraged to clarify or elaborate on their answers and to talk freely on any subject. The average length of interviews was 2 hours and 13 minutes. The transcripts were analyzed in the original language, using several coding processes and strategies recommended by field researchers (e.g., Berg 2007; Glaser and Strauss 1967; Lofland et al. 2006).

\section{Few romantic encounters among singles}

All never-married interviewees said they intended to marry one day, or had intended to when they were younger. Despite this intention, many single women went through a substantial proportion of their lives without dating at all. As seen in Table 1, sixteen out of twenty-eight single interviewees did not have an unmarried partner at the time of the interviews and for many of them the last relationship they had was several years earlier - in some cases more than a decade. Among these non-partnered single women, only one mentioned disinterest in forming intimate relationships currently (though she had planned to marry when she was younger). All others wished to have male romantic and/ or marital partners, and most of the interviewees were charming and attractive, so it appeared as if it would not be difficult for them to find a partner.

Many single women expressed the difficulties they had meeting single men. In 46-year-old Izumi's words, "I hardly see single men [...] I wonder whether they really exist". All of my single interviewees lived and worked in the Greater Tokyo Area, where the single population is the largest in Japan. My interviewees' stories indicate that the chances 
of finding romantic partners are limited for many women due to (i) gender segregation at work, (ii) men's long work hours, and (iii) women's own careers and work conditions.

\subsection{Gender segregation at work}

One theme that emerged from my interviewees' accounts of their work environments was that many women worked among other women and married men. This was partly due to vertical gender segregation: Japanese companies commonly separate employment tracks by gender, placing males on a career track and females on a non-career, dead-end, clerical track commonly known as the Office Lady (OL) (Brinton 1992; Ogasawara 1998; Rebick 2006). More than half of my interviewees were, however, not OLs. Instead, they worked in female-dominant occupations in smaller establishments such as social work, elderly care, department stores and other retail that involved women's products (e.g., women's clothing), nursing, teaching, as well as nutrition and cooking-related occupations. These women reported that "all" or "most" of their coworkers were women. This finding suggests that male and female workers in Japan are segregated horizontally as well, and most of these women in female-dominant occupations had few opportunities to intermingle with single men through work.

For those who worked as OLs for mid-size to large companies, the sex ratios seemed high (i.e., more males than females). Yet most of these interviewees also had little chance to see single male employees through work. For example, shy, never-married Kei (aged 35) worked for a company which hired more males than females, but she worked in a small branch office located far away from company headquarters. Her office dealt with tasks such as bookkeeping. She was the only new hire in her branch office when she got the job 13 years ago and all her coworkers were older women and married men. She said there seemed to be many single, male workers in non-office work positions, but they belonged to other offices so she never had opportunities to interact with them. Similarly, married Chie (aged 45) used to work as an OL for a company that was affiliated with a large construction-related corporation. There were four or five hundred employees in her company, and the majority of employees were males, but, she explained, "male workers in my office [which dealt with billing, etc.] were mostly old. Young men drew plans for A/C, plumbing and electricity [in other offices], or supervised construction workers at sites. I rarely had a chance to see them". These two women's stories suggest that tasks were often divided by gender and age in corporations, and this led to physical separation of young males and females in the workplace. 
There is an interesting cohort difference in corporate experience, however. Despite the space segregation, Chie married a man who worked for the same company. She met him in the 1980s on an annual company trip for employees (shanai ryokō). He was encouraged by his seniors to "grab her soon before other young guys get her" when he was about to be transferred to a smaller affiliated office $(s h u k k \bar{o})$. On the other hand, Kimi (aged 25, married), who works for a large bank, observed that "shanai kekkon [marriage between coworkers] may have become rarer now. [Among older male employees at her bank] it's common that their wives also worked for this bank. I heard that there used to be sport events (undōkai) or company trips, but we don't have them now. My boss says there are fewer opportunities [for single employees] to meet now because of that". The stories of Chie and Kimi suggest that young employees of Japanese corporations used to have chances to find marital partners through work, even when offices were gendered. Such chances seem to have been reduced after Japan's economic recession slashed budgets for company-sponsored events that integrated employees across sections. Shy women like Kei may have been approached by potential partners if companies had retained these events and activities.

Japan's recession may have further limited opportunities for women to meet young, single males at work. The following exchange I had with Megumi (aged 31, never married) illustrates the relevance of the hiring freeze.

Megumi: When I got hired [at age 22], most others were older. There was only one who was in my age group.

Author: Were there single men?

Megumi: No, hardly. It was the time that companies refrained from hiring new graduates, so my company wasn't hiring any new graduates for some years. Office workers, well, women quit for marriage, right? So they were hiring replacements [only for women]. The youngest man was 29 .

The clerical track has higher turnover rates, so women who left were replaced with new female hires. But this was not the case for men designated to a career track. Because of the gendered tracks, young women during the economic recession may have ended up working among older employees.

Several other interviewees worked for male-dominant companies, surrounded by male workers including young single men. Some of them dated or married men they met through work. Those who had 
romantic relationships through work were typically OLs. Women in career positions, however, had difficulties finding partners despite the high sex ratios in their work environments, which will be discussed in a later section.

\subsection{Men's long work hours}

\subsubsection{Single men's long work hours impede dating}

As already pointed out by various scholars (e.g., Sugimoto 2003) and the popular media, male Japanese employees work long hours. It is interesting to note that the never-married women in my interviews rarely mentioned this fact in association with their lack of dating opportunities, which seems to indicate how normative and taken for granted it is for men to work overtime. Some single women, however, mentioned men's busy work schedules as a reason for the dissolution of their past relationships. For example, Izumi (aged 46) said:

(2) He [her former boyfriend whom she dated in her early 30s] was staying overnight at work, or had to go somewhere immediately if something happened, and really, we couldn't make arrangements to meet [...] I probably should have married him. He was the one now I think I'd have been happy to live with. But at that time, he was too busy to see me [...] and the relationship just dissolved before going anywhere.

A second example is Yayoi (aged 31). She expected to marry her boyfriend, whom she had met in college and dated since she was 20 . To her, he was like her "clone", getting along with her in every way. When she was 27 or so, however, he broke up with her:

(3) I still don't understand why. Hmmm. He got really busy with work. He didn't seem to have any days off. Maybe he got exhausted physically and mentally. He was out of contact with me for about half a year, and then he e-mailed me saying he wanted to break up. He wrote that it wasn't like he came to dislike me, his mind came to be occupied with his job, and he felt distant from me [...] There was no problem with me, he said.

Yayoi liked soccer and bicycling, and recently a friend of hers introduced her to a man with the same interests. They dated once, and Yayoi thought that he "seemed nice" but they could not manage to arrange a date due to his long work hours, and the relationship ended before romance could unfold: 
(4) I wanted to see him a few more times to see if this works out. But he was also really busy with work. At the beginning of the week, he said he may be able to see me this day, and then in the middle of the week, he told me he couldn't. I couldn't leave a whole week open for him, you know?

\subsubsection{Absence of husbands in friends' marriages}

Though men's long work hours were mentioned by only a few nevermarried interviewees, for most of the married interviewees it was the most frequently discussed aspect of their married lives. Many were frustrated with, or recalled their frustration with, the absence of their husbands - especially when children were young. It was typical for husbands to come home around midnight and, in some cases, not until morning. Kyoko (aged 29), a newlywed, said she rarely had a chance to see her husband in person and managed to interact via e-mail. Mari (aged 38) had frequent fights with her husband, who was unavailable for the care of their young children, and expressed in tears her concerns over its negative effects on them. And Chie (aged 45) recalled the time her daughters referred to their father as if he were a guest arriving instead of a parent returning. They said, "Dad has arrived (kitayo)" instead of "is back home (kaette kitayo)".

Harumi was distressed because she was unable to please her husband who expects her "to welcome him happily when he comes home at 11 p.m. or midnight. But I often fall asleep as I put my [6-year-old] daughter to sleep. He doesn't like it". She further described her marriage as unhappy:

(5) I want him to pay attention to the family more. Spend more time, too. Also, we (pause) are no longer a couple. I hate it. We're not a couple, physically and emotionally. I'm so lonely and bored. He comes home, eats dinner, and goes to sleep. That's all. I feel, that's not what I expected. I'm really lonely. He has no time [for her]. I have a lot of time. It's disappointing [... On weekends] we try to go out as a family, but he says he has to work, so he works one day of the two. He's facing a computer screen and working [...] Sometimes I get really depressed.

Many never-married interviewees said they "never hear good things about marriage from [their] married friends". The absence of a husband or his affection was one of the complaints they frequently heard, and a good number of never-married interviewees expressed skepticism toward the possibility of a happy marriage. 


\subsection{3. "One-dimensional men" due to long work hours}

Some of the never-married interviewees, particularly those in their latethirties and forties, had chances to meet men through miai ('marital interviews') or other miai-like experiences, a traditional matchmaking system in Japan, in which a single man and woman are introduced through mediators as potential marital partners. These women said that all these men were exceptionally good in terms of jobs, education, income, and sometimes wealth (such as property holding). Yet these men did not appeal to them because they were "tsumaranai" or "omoshirokunai" ('uninteresting'), "pin to konai" ('unappealing'), or "o-katai" ('square'). I asked my interviewees to elaborate on this, and the following are some of the descriptions given of "uninteresting" men:

\section{(Izumi, aged 46)}

Izumi: These men were [...] commuting by car, so they just went back and forth between company and home [...] didn't go out to drink [after work...] They may have hobbies like computer or cars, but they don't go out to cities.

Author: Do you feel their world is too small?

Izumi: Their life sphere (seikatsu-ken) is small [...] We [single women] always hold passports so we can go abroad as soon as we find cheap tours. But they move around in a small area. I hate to say this but we're active and have much more experience. We're aggressive in finding interesting things [but they are not].

(7) (Seiko, aged 43)

Seiko: He worked for a bank [...] By hearing him talk, I could tell he had no personal time [...]

Author: Was he like someone who devoted his life to work?

Seiko: Rather than devoted to work, he was pressed by work so he did only work [...] No hobbies [...] I asked him what he does on days off, but he was mostly working. And if he had some free time, he drove. I asked him where he went. He said he drove to Kichijōji [a district of Tokyo] and drove back home (laughs).

(8) (Teruko, 41)

Teruko: I just couldn't talk with them. They're thinking only about money, and can't talk about anything cultural [...] I asked what he [one of the miai partners] liked to eat or where he liked to go. I thought that'd lead to some conversation. But whatever I asked, he was like "iyā̄" ['ah']. I felt, "What's 
this guy thinking? He's boring." [...] They're probably very serious, just focusing on the job.

(9) (Saori, aged 45)

Saori: $\quad$ For the second date, he said, "Let's meet for lunch" and we met in Ochanomizu. What kind of [fashionable] place was he going to take me? I was excited, you know? It turned out that he took me to Mansei [i.e., a chain restaurant] in a shopping mall building next to the train station. He insisted he wanted to go there [...] What!? I came all the way to Ochanomizu for this? (laughs)

The image of "uninteresting" men that emerged from these accounts fits that of Japan's "corporate warriors" who single-mindedly dedicate their time to their jobs (Dasgupta 2003). Perhaps due to such intense devotion, they lack cultural fluency or skills to communicate with women in a dating situation. In contrast, these single women seem to have rich cultural experience such as travel and an interest in gourmet food. All of these women are in their forties, the age cohort that, in their young adulthood, enjoyed the fruits of Japan's "bubble" economic boom of the 1980s. They are culturally savvy and seem to expect men to be savvier than themselves. This cultural gap may have contributed to the difficulties that women of this cohort experience when searching for partners who meet their expectations.

Married interviewees of this cohort also observed the mismatch between single women and men. Mari (aged 38) and Tamami (aged 45) were hesitant to matchmake their single girlfriends to male acquaintances (such as their husbands' coworkers) because these men are "leftovers" and "ojisan kusai" (i.e., 'old for their age'), whereas "my girlfriends are cute and beautiful" or "active". Single-minded devotion to work, expected of Japan's "corporate warriors," may have produced one-dimensional men lacking cultural fluency, and this may be part of the explanation for increased singlehood in Japan.

\subsection{Women's own careers and work conditions}

\subsubsection{Women's long work hours: No time and energy to date}

Several single interviewees worked in professional occupations or career-track positions at various sizes of companies. Many of them worked incredibly long hours, either currently or in the past. For instance, Tomomi, a 39-year-old social worker, worked until 11 p.m. regularly in her previous job. She quit it after she "began to have problems like pain in my hand and blood in my sputum". Other women, who 
were in marketing or advertising, explained that their work hours were highly unpredictable because they were affected by clients' demands. These women regarded going home at 9 p.m. "early" and many would often "hop on the last train" (which means going home past midnight) or even "work through the night" (tetsuya). A freelance illustrator, Natsumi, recalled that in her previous job in advertising, she regularly missed the last train and her company paid for a taxi that "cost more than my salary!" Some of these women moved out of their parents' homes in order to live closer to work, or quit their jobs because of late work hours.

Not surprisingly, overworked single women had little time or energy for socializing after work. Honoka (aged 32) described her typical weekday as follows:

(10) I don't see my friends after work because I can't tell what time I can get off work [...] When I can go home earlier [...] I have time and energy only to make dinner, go to a sento ['public bath'] and read books. On busy days, I go home on the last train. I eat kappu rämen [instant ramen noodles in cups] at work and work continuously.

The way these single women spent their weekends was not so glamorous either. All of them said they spent at least one day of the weekend alone in order to recuperate, to take care of chores such as cleaning and laundry, and/or just to enjoy time for themselves after days of stressful work. There were also women who worked on weekends as their work demanded. For these women, finding a date or developing romantic relationships was a challenge, as represented by the following account by Rumi (aged 45), the vice president of a small advertising company:

(11) Before going steady or anything, just to go out for dinner, I just can't even make any solid plans for a date (yakusoku). "I can probably meet you but if work comes up, I'd have to cancel the date at the last minute (dota-kyan)." They [men] don't like that. I also don't like to ask my subordinates [to take over my work] so I can date. I get so worried about my work during the date. So I have to find someone who can really understand my work demands and who won't get discouraged by a last-minute cancellation.

Midori (aged 36) often worked until 3 or 4 a.m., and felt that one of the reasons her past relationships did not last was that she "was so 
busy with work [...] and I had little chance to cook dinner for my boyfriends like other women do".

The issue was not just time constraints. For Izumi (aged 46), it was the unappealing nature of getting together with overworked males during her spare time:

(12) I don't like to see male friends on weekends because they're also busy [...] really tired. So if we get together, we're both tired (laughs), so it's not fun [...] I want to spend my weekends without talking about how hard we work. But [with those men] I'd have to listen to their nagging. I don't want that.

\subsubsection{Job competence that turns men off}

Unlike many other interviewees, women in professional occupations or career-track positions worked in male-dominant offices with many male coworkers. Yet these women were unable to form romantic relationships through work. They felt it was their competence at work that turned men off:

(13) (Yoko, aged 36, section manager)

I, well, win against men [...] I talk a lot, am very sociable, and am good at work. Men can't take me. They get jealous. They say, "You can live without men, can't you?"

(14) (Rumi, aged 45, vice-president)

I work overtime, even throughout the night (tetsuya), I'd never say I can't do it. And men [at work] think I'm unfeminine (kawaikunai). They don't like women who never say "I can't". They think I'm too strong. That's why they don't want me. Men think they can't nag [about their work] to women like me. They think we'd scold them (laughs). There was a young girl at my client company, who went, "(in a childish high-tone voice) $\mathrm{Oh}$, no, I got confused, ufufufufu [i.e, feminine chuckle]". What an idiot, I thought, but to men, she's probably cute.

(15) (Izumi, aged 46, marketing researcher)

Yeah, guys tell me, "You can solve everything on your own". [...They think] I can live by myself without their help. I'm independent [...] For men [of her age...] it's probably strange that women work.

These women said they "are unable to show my weak side", by which they "leave nothing for men to protect or support". Seiko was explicitly 
told by her male coworker that "girls should pretend to be stupid [...] or no men would approach them".

Such dedication to work should be praiseworthy from the corporate perspective, but it was traditionally expected only from male employees. When women cross the gender boundary by taking jobs seriously, they are no longer regarded as feminine. A comment made by Hitomi, a 36-year-old marketing consultant, summarizes how career work is associated with masculinity and how, by taking career jobs, women are assumed to have no interest in romance or marriage:

(16) I know they [men at work] are saying I don't want to marry, I'm just devoted to my career. I know they're saying I think men are stupid (laughs) [...] They say I'm exceptionally smart and good at work [...] I tell my boss that my ultimate dream is to become a housewife, to quit my job receiving a flower bouquet, but no one believes it [...] I don't think I could have shanai renai [i.e., romantic relationships with coworkers] [...] I think I'm a very different person when I'm "on" and "off" [i.e., "the job"] [...] When I'm in love relationships [...] that's the real me. But when I'm in the "work mode", I probably look like a devoted career woman. So men can't see me in the "love mode". I think I'm sealing up my feminine side [at work]. So I can't possibly get into love relationships with anyone at work.

It was the perception of these women that, because they took work seriously, they were regarded as masculine or unfeminine. Interestingly, this interpretation was shared by these women. They equated job competence with masculinity and desired men who were even better at work than themselves. To them, men with no career were "otokorashikunai" ('unmanly').

\section{Where do women find romantic partners?}

However short their dating history was, most interviewees did have some romantic relationships and some were married or engaged. In what social contexts had women met their current or former romantic partners? Among twelve married and three engaged interviewees, four met their partners while attending a four-year college, four met them through work, three through friends, one at a school reunion, one at a gym, one through an amateur radio club, and one at a music event. Because not all interviewees gave thorough information about their past relationships (either not remembering them well or avoiding the subject), my count of such relationships is not as accurate. With this 
limitation in mind, I estimate that more than one-third of their current and past relationships were formed while interviewees were in school. Once women graduated and had no continuing relationships with men they met at school, the most common ways to meet romantic partners were through work, friends, or social groups they belonged to (such as a golf class). Only four interviewees, including one lesbian woman, were approached by (or approached) current or past romantic partners or spouses in public places such as bars.

These findings indicate how important it is that women who wish to marry meet their partners at school or through work. Yet this study suggests that many women in Japan were deprived of opportunities to meet potential romantic partners at work. This means that the chances of marriage may be slim for women who do not form serious relationships while they are in school. In fact, some of my single interviewees wished painfully that they had pursued their former partners, or found occasions to meet single men, when they were in school. Kei (aged 35) said she "was mostly hanging out with my female friends when I was a student and also when I started working. I should have gone to gō-kon (i.e., parties for singles) and that kind of stuff [...] My life may have been different". Shizuka (aged 34) "had a boyfriend [she met in vocational school (senmon gakkō)] up until my first year of work. But I got busy with my job and we became distant". She has had "no boyfriend since then", and said "[I] wish I could go back to the time I was with him [...] it would have been fine [if she had married him]".

College life appears to be a situation in which young men and women form relationships with relative ease. As 30-year-old, nevermarried Momoe (aged 30) said, "It's much easier to get to know men in college, you know? I'd know which college they went to, know that they belong to sport clubs, I'd know all that beforehand". Momoe belonged to a sport club in college and there were many go-kon opportunities with other sport club members. But she was "too focused on the club activity" and "turned down all the go-kon [...] I should have gone to all those".

Many interviewees went to women-only two-year colleges or gendersegregated vocational schools, and it is possible that their opportunities for romance were already constrained during schooling. This possibility was mentioned by one of my interviewees, Saori (aged 45, clerical worker):

(17) I wish I went to college. Two years [of vocational schooling] were so busy and short. Four-year college students [...] were like between kids and adults [...] They had lots of free time. There are more opportunities to meet different kinds of people in college. I 
went to English vocational school so most [students] were girls. I had to study hard and didn't have much time to play. I didn't have male friends [...] If I had male friends, I think I'd have understood men better [...] I think I couldn't handle men well, dating and stuff, because of that. I think I had a bad start (laughs sadly).

Saori implied that due to gendered schooling, she was deprived not only of chances to meet a variety of men, but also of the communication skills needed to interact with the opposite sex.

\section{Discussion and conclusion}

My interviewees' stories suggest that Japanese women's opportunities to form romantic relationships are limited severely by structural context. Many women in this study were segregated from men at work, vertically and horizontally, and had little chance to interact with single men through work. Accounts by Chie, Kei, and Kimi indicate that corporations used to sponsor gender-integrated recreational activities for employees, which may have played a significant role in matchmaking in the past. Company budgets for such activities seem to have dried up as Japan entered an economic recession in the mid-1990s. As mentioned by Megumi, most Japanese corporations coped with the recession with hiring freezes on young employees (rather than layoffs of older ones) (Genda 2005; Jung and Cheon 2006). These corporate policies after the recession may have exacerbated gender segregation at work.

Japan's corporate culture, which demands employee loyalty through overtime work, has been criticized for its negative effects on workers' health, family life, women's career opportunities, etc. (e.g., Sugimoto 2003). My study shows that long work hours might have detrimental effects on yet another aspect of individuals' lives: their opportunities for intimate relationships. Women had limited time and opportunities to meet potential partners or develop romantic relationships due to men's and/or their own long work hours. Many married women in the study expressed discontent with the absence of husbands at home and, having heard negative stories from their married friends, many single women held ambivalent views toward marriage. Long work hours expected of male corporate workers may have shaped many of such men into "one-dimensional" corporate warriors who are not culturally attuned, sophisticated gentlemen. Women in career-track or professional occupations worked extremely long hours as well, and by doing so, were regarded as having little interest in romance or marriage. 
These findings point to a persistence of gendered practices in the sphere of work and their relevance to increased singlehood. More subtly, my study indicates the persistent acceptance of gender inequality, or male superiority, among women. My interviewees, who rejected elite corporate men for not possessing the same cultural and leisure experience as they did themselves, preferred middle-class men in white-collar occupations for their marital partners. They were disappointed with the former because they were unable to lead women, or because the men did not stand above women in cultural knowledge. Women in professional positions called themselves "unfeminine", and from this I sensed that even women in relatively high economic positions accepted the idea that their professional role was improper for women. Some scholars (e.g., Nakano 2010) view increased singlehood among Japanese women as a type of resistance to convention or traditional gender arrangements. Others (e.g., Kelsky 2001; Nemoto 2008) observed a lack of conscious agency in the pursuit of gender equality among young single women in Japan. My study is in agreement with the latter. I think increased singlehood has been largely caused by structural barriers and the persistence of traditional beliefs regarding gender hierarchy. Increased singlehood, however, may undermine existing gender arrangements. Despite the absence of agency, the lifestyle change itself could be a force for social change (Kelsky 2001; Mathews 2004).

Lastly, gender segregation in schooling may be an important factor in chances for romance. Educational homogamy has increased among the college-educated (Raymo and Iwasawa 2005; Shirahase 2005). This may be because most two-year colleges are women-only and many high schools and vocational schools are segregated by gender. As miai marriage has declined (Tokuhiro 2010), lower-educated women may face disadvantages when searching for potential partners. Future research should investigate the effects schooling has on the opportunity to meet romantic partners.

All of these findings show how individual desires for intimate relationships are constrained by structural context. A Western-style marriage, based on emotional connectedness as opposed to practicality, is becoming the ideal in many societies (Wardlow and Hirsch 2006), and Japan is no exception. Other surveys (NIPSSR 2008) come to similar conclusions as my analysis, showing that most single women in Japan today favor love-based marriage over traditional miai marriage. Such desires are, however, unmet for many women as chances for romantic encounters and development of relationships are limited by corporate practices and traditional gender ideology. This implies a tension between the existing power structure and increasingly individualistic desires. Such a power structure did not pose barriers for the past genera- 
tion, for whom miai or miai-like arranged marriage was the norm (Tokuhiro 2010). But for today's women, it is important that marriage involve romance. This expectation is hard to meet when social structure impedes chances for romance. My argument is that this limitation in opportunity has played a significant role in Japan's increased singlehood.

Single women in Japan have been labeled "Christmas cake", 4 "parasite singles", 5 and "make-inu" ('defeated dogs'). These labels stigmatize women as problematic, selfish, materialistic, or pathetic. Because increased singlehood is a direct cause of declined Japanese fertility rates (MHLW 2003), single women are often regarded by the Japanese state as a threat to Japan's future, and this may explain why state policies tend to neglect single women's issues (Nakano and Wagatsuma 2004). At the same time, single women are sometimes portrayed as "free" and "independent", focusing their lives on self-actualization (Nakano and Wagatsuma 2004; Ueno 2008). Such an image seems positive and empowering at a glance, but contains danger. First of all, my study as well as other research (e.g., Kelsky 2001; Nemoto 2008; Tokuhiro 2010) indicates that most never-married women do not choose to remain single, and wish to marry one day. Second, many of the nevermarried interviewees earned low incomes and expressed concerns over their futures, including economic security and psychological health. The image of the free, independent single woman may alienate or further stigmatize those who cannot live up to this image. Lastly, such a public image may frame single women as unworthy of social support, which would justify the neglect of their issues in government policies.

Focusing on structural barriers to marriage in Japan, this study has shown that individual desires are in conflict with the existing power structure, and this conflict creates risks to individual well-being and with declined fertility as one consequence - to society as a whole. On the basis of in-depth accounts collected from Japanese women, I argue that traditional gender ideology and corporate culture contributed to Japan's increased singlehood by limiting chances for romance.

Akiko Yoshida (yoshidaa@uww.edu) received her Ph.D. in sociology in 2010 from the University of Oklahoma, and is Assistant Professor of Sociology at the University of Wisconsin, Whitewater. She has conducted research in Japan and the United States on singlehood, women in party sales, and father involvement. Publications include articles published in Marriage and Family Review and Journal of Family Issues, and a book chapter in Women at Work: Tupperware, Passion Parties, and Beyond (edited by L. Susan Williams and Michelle Bemiller, 2011). 
Her research interests center upon the manner in which intersections of class, gender, race, ethnicity, and nationality shape singlehood, intimate relationships, and sexuality.

\section{Notes}

1. This paper reports findings that emerged from inductive analysis of data collected originally for my dissertation research.

2. According to Shirahase (2005), marriage rates are lower among men with lower income for the more recent cohort, an observation that supports the theory by Oppenheimer and her colleagues.

3. The interview guide is available upon request but can also be found in the author's dissertation (Yoshida 2010).

4. The term "Christmas cake" meant that single women past age 25 are leftovers like Christmas cake after the 25th (of December).

5. The term "parasite singles" refers to both single men and women.

\section{References}

Atoh, Makoto. 1994. Mikonka bankonka no shinten: Sono dōkō to haikei [The recent rise in the proportion of singles and the postponement of marriage in Japan]. Kazoku Shakaigaku Kenkyü [Japanese journal of family sociology] 6. 517.

Beck, Ulrich \& Elisabeth E. Beck-Gernsheim. 2005. Individualization: Institutionalized individualism and its social and political consequences. London: Sage.

Becker, Gary S. 1993 [1981]. Treatise on the family. Cambridge, MA: Harvard University Press.

Berg, Bruce L. 2007. Qualitative research methods for the social science, 6th edn. Boston: Pearson.

Brinton, Mary C. 1992. Women and the economic miracle: Gender and work in postwar Japan. Berkeley: University of California Press.

Cherlin, Andrew J. 2004. Deinstitutionalization of American marriage. Journal of Marriage and Family 66 (4). 848-861.

Dasgupta, Romit. 2003. Creating corporate warriors: The "salaryman" and masculinity in Japan. In Kam Louie \& Morris Low (eds.), Asian masculinities: The meaning and practice of manhood in China and Japan, 118-134. London \& New York: RoutledgeCurzon.

Genda, Yūji. 2005. A nagging sense of job insecurity: The new reality facing Japanese youth. Tokyo: International House of Japan.

Giddens, Anthony. 1991. Modernity and self-identity: Self and society in the later modern age. Stanford, CA: Stanford University Press.

Glaser, Barney G. \& Anselm L. Strauss. 1967. The discovery of grounded theory: Strategies for qualitative research. Chicago: Aldine.

Guttentag, Marcia \& Paul F. Secord. 1983. Too many women?: The sex ratio question. Beverly Hills, CA: Sage.

Hirayama, Yosuke \& Misa Izuhara. 2008. Women and housing assets in context of Japan's home owning democracy. Journal of Social Policy 37 (4). 641-660.

Hiroshima, Kiyoshi. 1999. 1970-1990-nen ni okeru joshi no mikonritsu jōshō no yōin bunkai [A decomposition of increase in proportion never-married for women in Japan from 1970 to 1990]. Keizai Kagaku Ronshü [Journal of economics] 25. $1-25$. 
Iwama, Akiko. 1999. Bankonka to mikonsha no raifu sutairu [The postponement of marriage in Japan and the single lifestyle]. Jinkō Mondai Kenky $\bar{u}$ [Journal of population problems] 55 (2). 39-58.

Jung, EeHwan \& Byung-you Cheon. 2006. Economic crisis and changes in employment relations in Japan and Korea. Asian Survey 46 (3). 457-476.

Kelsky, Karen. 2001. Women on the verge: Japanese women, Western dreams. Durham, NC \& London: Duke University Press.

Kerbo, Harold R. 2009. Social stratification and inequality: Class conflict in historical, comparative, and global perspective, 7th edn. Boston: McGraw-Hill.

Lofland, John, David Snow, Leon Anderson \& Lyn H. Lofland. 2006. Analyzing social settings: A guide to qualitative observation and analysis, 4th edn. Belmont, CA: Wadsworth/Thomson Learning.

Mathews, Gordon. 2004. Seeking a career, finding a job: How young people enter and resist the Japanese world of work. In Gordon Mathews \& Bruce White (eds.), Japan's changing generations, 122-136. London \& New York: Routledge.

MHLW (Ministry of Health, Labor, and Welfare). 2003. Kōsei rōdōshō hakusho katsuryokuaru kōreishazō to sedaikan no aratana kankei no kōchiku [White paper on labor and economy - Construction of an image of energetic old people as well as new intergenerational relationship]. http://www.mhlw.go.jp/wp/ hakusyo/kousei/03/dl/data.pdf (accessed 4 November 2010).

MIAC (Ministry of Internal Affairs and Communication). 2008. Shinkō suru shōshi kōreika [Fertility decline and aging]. http://www.stat.go.jp/data/kokusei/2005/ sokuhou/01.htm (accessed 4 November 2010).

Nakano, Lynne Y. 2010. Working and waiting for an "appropriate person": How single women support and resist family in Japan. In Richard Ronald \& Allison Alexy (eds.), Home and family in Japan: Continuity and transformation, 229267. London \& New York: Routledge.

Nakano, Lynne \& Moeko Wagatsuma. 2004. Mothers and their unmarried daughters: An intimate look at generational change. In Gordon Mathews \& Bruce White (eds.), Japan's changing generations, 137-153. London \& New York: Routledge.

Nemoto, Kumiko. 2008. Postponed marriage: Exploring women's views of matrimony and work in Japan. Gender and Society 22(2). 219-237.

NIPSSR (National Institute of Population and Social Security Research). 2008. Dai 13-kai shusshō dōkō kihon chōsa [The thirteenth Japanese national fertility survey]. http://www.ipss.go.jp/ps-doukou/j/doukou13_s/Nfs13doukou_s.pdf (accessed 4 November 2010).

Ogasawara, Yuko. 1998. Office ladies and salaried men: Power, gender, and work in Japanese companies. Berkley: University of California Press.

Oppenheimer, Valerie Kincade. 2000. The continuing importance of men's economic position in marriage formation. In Linda J. Waite (ed.), The ties that bind: Perspectives on marriage and cohabitation, 283-301. New York: Aldine de Gruyter.

Oppenheimer, Valerie Kincade, Matthijs Kalmijn \& Nelson Lim. 1997. Men's career development and marriage timing during a period of rising inequality. Demography 34 (3). 311-330.

Raymo, James M. 2003. Educational attainment and the transition to first marriage among Japanese women. Demography 40 (1). 83-103.

Raymo, James M. \& Miho Iwasawa. 2005. Marriage market mismatches in Japan: An alternative view of the relationship between women's education and marriage. American Sociological Review 70 (5). 801-822.

Raymo, James M., Miho Iwasawa \& Larry Bumpass. 2009. Cohabitation and family formation in Japan. Demography 46 (4). 785-803. 
Rebick, Marcus. 2006. Changes in the workplace and their impact on the family. In Marcus Rebick \& Ayumi Takenaka (eds.), The changing Japanese family, 75-93. London \& New York: Routledge.

Retherford, Robert D., Naohiro Ogawa \& Rikiya Matsukura. 2001. Late marriage and less marriage in Japan. Population and Development Review 27 (1). 65-102.

Rindfuss, Ronald R., Minja Kim Choe, Larry L. Bumpass \& Noriko O. Tsuya. 2004. Social networks and family change in Japan. American Sociological Review 69 (6). $838-861$.

Shirahase, Sawako. 2005. Shōshi kōreika no mienai kakusa: Jendā, sedai, kaisō no yukue [The unseen gaps in an aging society: Locating gender, generation and class in Japan]. Tokyo: University of Tokyo Press.

Sugimoto, Yoshio. 2003. An introduction to Japanese society, 2nd edn. Cambridge: Cambridge University Press.

Tachibanaki, Toshiaki. 2006. Kakusa shakai [Unequal society]. Tokyo: Iwanami Shinsho.

Tokuhiro, Yoko. 2010. Marriage in contemporary Japan. London \& New York: Routledge.

Tsuya, Noriko O. 2000. Women's empowerment, marriage postponement, and gender relations in Japan: An intergenerational perspective. In H. B. Presser \& G. Sen (eds.), Women's empowerment and demographic processes: Moving beyond Cairo, 318-348. Oxford: Oxford University Press.

Tsuya, Noriko O. \& Karen Oppenheim Mason. 1995. Changing gender roles and below replacement fertility in Japan. In K. O. Mason \& A-M Jensen (eds.), Gender and family change in industrialized countries, 139-167. Oxford: Clarendon Press.

Ueno, Chizuko. 2008. Ohitorisama no rōgo [Aging for one]. Tokyo: Hōken.

Van de Kaa, Dirk. 1987. Europe's second demographic transition. Population Bulletin 42 (1). 3-57.

Wardlow, Holly \& Jennifer S. Hirsch. 2006. Introduction. In J. S. Hirsch \& H. Wardlow (eds.), Modern loves: The anthropology of romantic courtship and companionate marriage, 1-31. Ann Arbor: The University of Michigan Press.

Yoshida, Akiko. 2010. Cultural lag, anomie, and single women in Japan. Norman, OK: University of Oklahoma dissertation. 